\title{
Changes in Glucose and Glutamine Lymphocyte Metabolisms Induced by Type I Interferon $\alpha$
}

\author{
Francisco Navarro, ${ }^{1}$ Aline V. N. Bacurau, ${ }^{2}$ Andréa Vanzelli, ${ }^{2}$ Marcela Meneguello-Coutinho, ${ }^{3}$ \\ Marco C. Uchida, ${ }^{4}$ Milton R. Moraes, ${ }^{5}$ Sandro S. Almeida, ${ }^{5}$ Frederick Wasinski, ${ }^{5}$ \\ Carlos C. Barros, ${ }^{5}$ Martin Würtele, ${ }^{5,6}$ Ronaldo C. Araújo, ${ }^{5}$ Luís F. B. Costa Rosa, ${ }^{4}$ \\ and Reury F. P. Bacurau ${ }^{7}$ \\ ${ }^{1}$ Department of Physical Education, Federal University of Maranhão, 14040-904 São Paulo, SP, Brazil \\ ${ }^{2}$ School of Physical Education and Sport, University of São Paulo, 5508-900 São Paulo, SP, Brazil \\ ${ }^{3}$ Department of Physical Education, Presbyterian University Mackenzie, 01302-907 São Paulo, SP, Brazil \\ ${ }^{4}$ Institute of Biomedical Sciences, University of São Paulo, 5508-900 São Paulo, SP, Brazil \\ ${ }^{5}$ Department of Biophysics, Federal University of São Paulo, 04023-062 São Paulo, SP, Brazil \\ ${ }^{6}$ Department of Science and Technology, Federal University of São Paulo, 12231-280 São José dos Campos, SP, Brazil \\ ${ }^{7}$ Escola de Artes, Ciências e Humanidades, Universidade de São Paulo, Avenida Arlindo Bettio, 1000, 03828-000 São Paulo, SP, Brazil
}

Correspondence should be addressed to Reury F. P. Bacurau, reurybacurau@usp.br

Received 19 October 2010; Accepted 8 December 2010

Academic Editor: Giamila Fantuzzi

Copyright (c) 2010 Francisco Navarro et al. This is an open access article distributed under the Creative Commons Attribution License, which permits unrestricted use, distribution, and reproduction in any medium, provided the original work is properly cited.

In lymphocytes (LY), the well-documented antiproliferative effects of IFN- $\alpha$ are associated with inhibition of protein synthesis, decreased amino acid incorporation, and cell cycle arrest. However, the effects of this cytokine on the metabolism of glucose and glutamine in these cells have not been well investigated. Thus, mesenteric and spleen LY of male Wistar rats were cultured in the presence or absence of IFN- $\alpha$, and the changes on glucose and glutamine metabolisms were investigated. The reduced proliferation of mesenteric LY was accompanied by a reduction in glucose total consumption (35\%), aerobic glucose metabolism (55\%), maximal activity of glucose-6-phosphate dehydrogenase (49\%), citrate synthase activity (34\%), total glutamine consumption $(30 \%)$, aerobic glutamine consumption $(20.3 \%)$ and glutaminase activity $(56 \%)$. In LY isolated from spleen, IFN $\alpha$ also reduced the proliferation and impaired metabolism. These data demonstrate that in LY, the antiproliferative effects of IFN $\alpha$ are associated with a reduction in glucose and glutamine metabolisms.

\section{Introduction}

Interferon alpha (IFN $\alpha$ ) was initially characterized as an antiviral cytokine. Subsequently, several of its effects were demonstrated. Among them, the antiproliferative effect is the best characterized [1] and allows IFN $\alpha$ to be used in the treatment of several tumors [2]. IFN $\alpha$ proteins are produced both in response to infections as well as constitutively and have a wide range of functions on different cell types including the modulation of lymphocyte (LY) activity $[3,4]$. Thus, this cytokine is able to modulate the proliferation, survival, and differentiation of LY [1]. The antiproliferative effect of IFN $\alpha$ on LY is related, for example, to the arrest of the cell cycle [2] and inhibition of both protein synthesis and amino acid incorporation [5].

LY activation is characterized by a state of high biochemical activity [6] required to sustain proliferation and the synthesis of several endogenous products in these cells [7-10]. Because in LY glucose and glutamine consumptions are strictly coupled to their cellular functions [11], the uptake and consumption of both substrates is markedly increased to cope up with the demands of activation. In this scenario, not only precursor molecules used in DNA and RNA synthesis are provided [11] but also the energy required 
by the biosynthetic processes [12]. Glucose and glutamine metabolisms (and consequently LY functions) can be determined by the in vitro measurement of some key enzymes from glycolysis, glutaminolysis, and the citric acid cycle [13]. In fact, we have previously determined the changes in LY functionality induced by different experimental conditions using this methodology [14-16].

Considering the antiproliferative effects of IFN $\alpha$ and the importance of the glucose and glutamine metabolisms for LY, it is tempting to speculate that IFN $\alpha$ affects the glucose and glutamine metabolisms of these cells. Thus, the aim of the present study was to evaluate the metabolism of glucose and glutamine in LY from mesenteric lymph nodes and the spleen of rats cultured in the presence of IFN $\alpha$. Our hypothesis is that the antiproliferative effect of IFN $\alpha$ in lymphocytes can be associated to a reduction of the glucose and glutamine metabolism.

\section{Material and Methods}

2.1. Animals and Reagents. Male adult Wistar rats weighing $180 \mathrm{~g}$ (8 weeks old) from the Animal Breeding Unit, Institute of Biomedical Sciences, University of São Paulo, São Paulo, Brazil, were housed in a temperature-controlled room at $23^{\circ} \mathrm{C}$ under a photoperiod regimen of a $12: 12 \mathrm{hrs}$ light: dark cycle (lights on at 8:00 am) with water and commercial food ad libitum. These animals were maintained in accordance with the guidelines of the Brazilian Association for Laboratory Animal Science, and all experimental procedures were approved by the Ethical Committee on Animal Experimentation of the Institute of Biomedical Sciences, University of São Paulo. The $\left[\mathrm{U}_{-}{ }^{14} \mathrm{C}\right]$-glucose, $\left[\mathrm{U}_{-}{ }^{14} \mathrm{C}\right]$-glutamine, and $\left[2-{ }^{14} \mathrm{C}\right]$-thymidine were purchased from Amersham (Little Chalfont, Buckinghamsthire, UK). All other reagents including IFN- $\alpha$ were purchased, unless specified, from Sigma (St Louis, MO, USA) or Merck (Darmstadt, Germany).

2.2. LY from Spleen and Mesenteric Lymph Nodes. Organs were extracted and cells extracted by pressing tissues against a steel mesh as described by Ardawi and Newsholme [17]. The cell suspension was filtered (Whatman plc, Middlesex, UK) and centrifuged at $150 \mathrm{~g}$ for $15 \mathrm{~min}$ at $4^{\circ} \mathrm{C}$. The total contamination with macrophages was lower than $1 \%$.

2.3. Lymphocyte Proliferation. LY from spleen and mesenteric LY were cultivated in 96-well plates $\left(1 \times 10^{5}\right.$ cells per well; Corning, One Riverfront Plaza, NY, USA) under sterile conditions in GIBCO RPMI 1640 medium for $48 \mathrm{hrs}$ at $37^{\circ} \mathrm{C}$ in an artificially humidified atmosphere of $5 \% \mathrm{CO}_{2}$ in a microprocessor incubator (LAB LINE, Boston MA). Cells were also cultivated in the presence of concanavalin A (ConA; $5 \mu \mathrm{g} / \mathrm{mL}$ ), lipopolysaccharide (LPS; $10 \mathrm{mg} / \mathrm{mL}$ ) or recombinant rat recombinant IFN $\alpha(1,000 \mathrm{U} / \mathrm{mL}$; added in the beginning of culture periods). After $48 \mathrm{hrs}$ in culture, more than $98 \%$ of the lymphocytes were still viable, as measured by trypan blue exclusion. The cells were labeled with $7400 \mathrm{~Bq}{ }^{14} \mathrm{C}$-thymidine (Amersham-GE Health-care, Uppsala, Sweden) and diluted in sterile PBS yielding a final concentration of $1 \mu \mathrm{g} / \mathrm{mL}$. The cells were maintained under these conditions for an additional $15 \mathrm{hrs}$ and automatically harvested using a multiple-cell harvester and filter paper (Skatron Combi, Sulfolk, UK). The paper discs containing the labeled cells were counted in $5 \mathrm{~mL}$ Bray's scintillation cocktail in a Beckman-LS 5000TD liquid scintillator (Beckman Instruments, Fullerton, CA).

2.4. Incubation Procedure. LY from spleen and mesenteric LY were incubated $\left(1 \times 10^{6}\right.$ cells per flask $)$ at $37^{\circ} \mathrm{C}$ in Krebs Ringer medium with $2 \%$ fat-free bovine serum albumin (BSA) in the presence of glucose $(5 \mathrm{mM})$ or glutamine $(2 \mathrm{mM})$. After $1 \mathrm{hr}$, cells were disrupted with $200 \mu \mathrm{L} 25 \%$ $(\mathrm{w} / \mathrm{v})$ trichloroacetic acid, and the sample was neutralized with $100 \mu \mathrm{L}$ of $0.5 \mathrm{M}$ Tris containing $2.0 \mathrm{M} \mathrm{KOH}$ for the measurement of metabolites. Glucose consumption was determined as previously described by Trinder [18]. Lactate production was determined as previously described by Engle and Jones [19]. Glutamine consumption was determined using the method described by Windmueller and Spaeth [20]. All spectrophotometric measurements were performed in a Hitachi U-2001 spectrophotometer (Hitachi, Tokyo, Japan) at $25^{\circ} \mathrm{C}$.

2.5. Glucose and Glutamine Oxidation. The ${ }^{14} \mathrm{CO}_{2}$ produced from ${ }^{14} \mathrm{C}$-glucose and ${ }^{14} \mathrm{C}$-glutamine oxidation was determined as described by Curi et al. [21]. LY were incubated for $1 \mathrm{hr}$ in the presence of one of the radiolabeled substrates in a sealed Erlenmeyer flask $(25 \mathrm{~mL})$ with one compartment for cell incubation and a second one for $\mathrm{CO}_{2}$ collection, as previously described by Kowalchuck et al. [22]

2.6. Enzymes. The activities of glucose-6-phosphate dehydrogenase $(\mathrm{G} 6 \mathrm{PDH})$, hexokinase $(\mathrm{HK})$, and glutaminase (GLUTase), enzymes that catalyse, respectively, the first reaction of pentose phosphate and glycolitic and glutaminolytic pathways, were measured as previously described by Bergmeyer et al. [23], Crabtree and Newsholme [24], and Curthoys and Lowry [25], respectively. Citrate synthase (CS), an important enzyme from the Krebs cycle, was measured as described by Alp et al. [26]. The extraction media for enzymes were: $25 \mathrm{mM}$ Tris- $\mathrm{HCl}$ buffer containing $1 \mathrm{mM}$ EDTA and $30 \mathrm{mM} \beta$-mercaptoethanol (for HK; $\mathrm{pH}$ 7.4), $50 \mathrm{mM}$ Tris-HCl containing $1 \mathrm{mM}$ EDTA (for GLUTase: $\mathrm{pH}$ 8.6), $50 \mathrm{mM}$ Tris- $\mathrm{HCl}$ containing $1 \mathrm{mM}$ EDTA (for CS; $\mathrm{pH}$ 7.4), and $50 \mathrm{mM}$ Tris- $\mathrm{HCl}$ containing $1 \mathrm{mM}$ EDTA (for G6PDH; $\mathrm{pH}$ 8.0). For all enzyme assays, Triton X-100 was added to the medium to a final concentration of $0.05 \%$ $(\mathrm{v} / \mathrm{v})$. For HK activity, the following incubation medium was used ( $\mathrm{pH}$ 7.5); $75 \mathrm{mM}$ Tris- $\mathrm{HCl}$ containing $7.5 \mathrm{mM} \mathrm{MgCl}_{2}$, $0.8 \mathrm{mM}$ EDTA, $1.5 \mathrm{mM} \mathrm{KCl}, 4.0 \mathrm{mM} \beta$-mercaptoethanol, $0.4 \mathrm{mM}$ creatine phosphate, $1.8 \mathrm{U}$ creatine kinase, $1.4 \mathrm{U}$ glucose-6-posphate dehydrogenase, and $0.4 \mathrm{mM} \mathrm{NADP}{ }^{+}$. The assay buffer for CS activity ( $\mathrm{pH}$ 8.1) consisted of $100 \mathrm{mM}$ Tris- $\mathrm{HCl}, 0.2 \mathrm{mM}$ 5.5'-dithio-bis-2-nitrobenzoic acid, $15 \mathrm{mM}$ acetyl-coenzyme $\mathrm{A}$, and $0.5 \mathrm{mM}$ oxaloacetate. The buffer for G6PDH ( $\mathrm{pH} 7.6$ ) consisted of $86 \mathrm{mM}$ Tris$\mathrm{HCl}$ containing $6.9 \mathrm{mM} \mathrm{MgCl}_{2}, 0.4 \mathrm{mM} \mathrm{NADP}{ }^{+}, 1.2 \mathrm{mM}$ 
TABLe 1: Proliferation of splenocytes and mesenteric lymphocytes cultured in the presence or absence of IFN $\alpha$.

\begin{tabular}{lccc}
\hline & No add & ConA & LPS \\
\hline C LFN & $1003.6 \pm 65.3$ & $1954.5 \pm 87.5$ & $1753.1 \pm 103.2$ \\
IFN LFN & $875.4 \pm 65.8^{\dagger}$ & $1478.3 \pm 76.3^{\dagger}$ & $1165.9 \pm 55.9^{\dagger}$ \\
C SPL & $1231.2 \pm 81.9$ & $2309.6 \pm 117.4$ & $1987.3 \pm 80.2$ \\
IFN SPL & $845.1 \pm 76.4^{\star}$ & $1543.9 \pm 67.1^{\star}$ & $1456.3 \pm 87.3^{\star}$ \\
\hline
\end{tabular}

The values are expressed as disintegrations per minute (DPM) and are presented as mean \pm SEM of 9 experiments. ConA: concanavalin A; LPS: lipopolysaccharide; C LFN: mesenteric lymphocytes incubated in the absence of IFN $\alpha$; IFN LFN; mesenteric lymphocytes cultured with IFN $\alpha$; C SPL: splenocytes cultured in the absence of IFN $\alpha$; SPL IFN splenocytes cultured with IFN $\alpha .{ }^{\dagger} P<.05$ compared to C LY group. $P<.05$ compared with C SPL group.

glucose-6-phosphate, and $0.5 \%$ Triton X-100. The assay for GLUTase ( $\mathrm{pH}$ 8.6) consisted of $50 \mathrm{mM}$ potassium phosphate buffer containing $0.2 \mathrm{mM}$ EDTA and $20 \mathrm{mM}$ glutamine. In all cases, the final assay volume was $1.0 \mathrm{~mL}$. CS activity was determined by absorbance at $412 \mathrm{~nm}$ and the other enzymes at $340 \mathrm{~nm}$. All spectrophotometric measurements were performed in a Hitachi U-2001 spectrophotometer (Hitachi, Tokyo, Japan) at $25^{\circ} \mathrm{C}$.

2.7. Protein Measurement. The protein content of the samples was measured by the method of Bradford [27]. BSA was used as standard.

2.8. Statistical Analysis. Analysis was performed using GraphPad-Prism. When differences among the groups were detected by two-way factorial ANOVA, the Tukey test was used. The level of significance of $P<.05$ was chosen for all statistical comparisons. Data are presented as means \pm SEM.

\section{Results}

3.1. Lymphocytes from Mesenteric Lymph Nodes. Lymphocytes obtained from mesenteric lymph nodes cultured in the presence of IFN $\alpha(1000 \mathrm{U} / \mathrm{mL}$ for $48 \mathrm{hrs})$ presented a reduced proliferative index under all evaluated conditions when compared to cells cultivated without this cytokine (reduction by $13 \%, 24.4 \%$, and $33.5 \%$, when compared to control, concanavalin A, and LPS experiments, respectively) (Table 1). This reduction was accompanied by a reduction of $49.2 \%$ of the maximal activity of glucose-6-phosphate dehydrogenase (G6PDH) (Figure 1). Glucose utilization for energetic processes was also reduced by IFN $\alpha$ as can be seen by a $35.3 \%$ reduction in glucose consumption and a $55 \%$ decrease in glucose decarboxylation (Figure 2). On the other hand, maximal activity of hexokinase (HK) increased by 1.4fold in cells incubated with IFN $\alpha$ (Figure 1). The maximal activities of citrate synthase (CS) and glutaminase (GLUTase assay) were also reduced in lymphocytes incubated in the presence of IFN $\alpha$ when compared to cells incubated without the cytokine (34\% and 56\% reduction, resp.) (Figure 1). In agreement with the result of the GLUTase assay, glutamine consumption $(-30.2 \%)$ and glutamine aerobic utilization

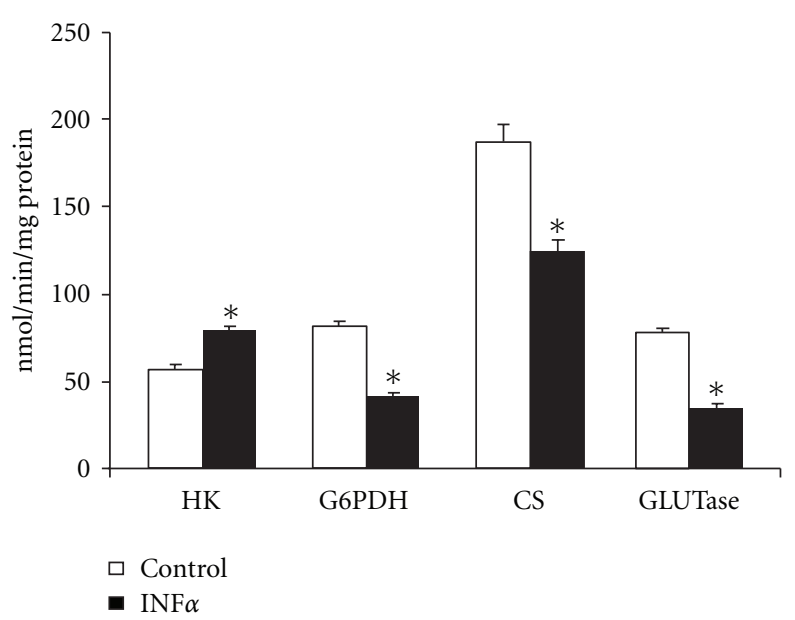

FIGURE 1: Maximal activity of enzymes of mesenteric lymphocytes cultured in the presence or absence of IFN $\alpha$. The results are expressed as $\mathrm{nmol} / \mathrm{min}$ per $\mathrm{mg}$ of protein and represent the mean \pm SEM of 9 experiments. HK: hexokinase; G6PDH: glucose-6phosphate dehydrogenase; CS: citrate synthase; GLUTase: phosphate dependent glutaminase. ${ }^{*} P<.05$ for comparison with the control (C) group.

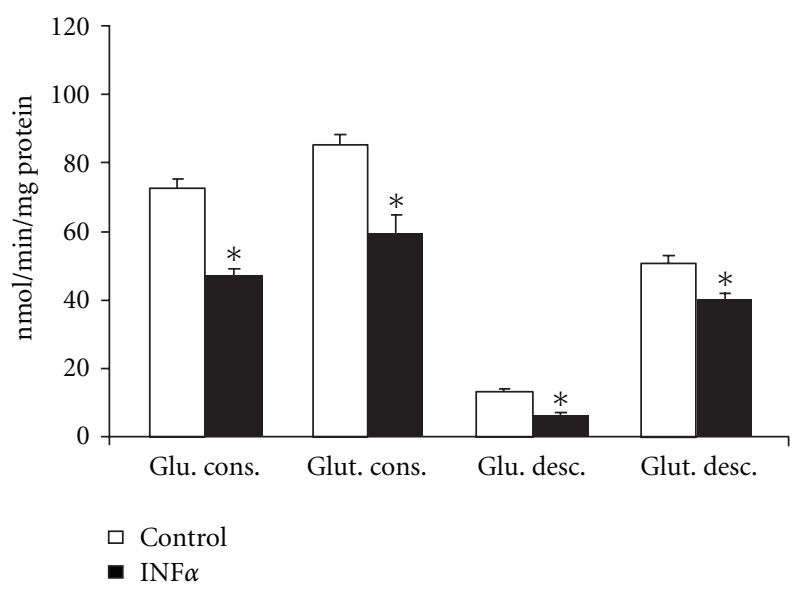

Figure 2: Consumption and decarboxylation of glucose and glutamine by mesenteric lymphocytes cultured in the presence or absence of IFN $\alpha$. The results are expressed as $\mathrm{nmol} / \mathrm{min}$ per $\mathrm{mg}$ of protein and represent the mean \pm SEM of 9 experiments. ${ }^{*} P<.05$ for comparison with the control (C) group.

$(-20.3 \%)$ were reduced by IFN $\alpha$ in comparison to cells incubated without the cytokine (Figure 2).

3.2. Lymphocytes from Spleen. In lymphocytes obtained from the spleen, IFN $\alpha$ promoted the same pattern of changes in glucose and glutamine metabolism observed in lymphocytes from mesenteric lymph nodes. In comparison to control cells cultivated without IFN $\alpha$, lymphocytes from the spleen presented a reduced proliferative index in all conditions evaluated (reduction by $31.3 \%, 33.1 \%$, and $27 \%$, 
when compared with control, concanavalin A, and LPS experiments, resp.) (Table 1). As observed for lymphocytes obtained from mesenteric lymph nodes, most of the features of glucose metabolism in LY from the spleen were reduced by IFN $\alpha$, as can be seen by the reduction of $43 \%$ in maximal G6PDH activity (Figure 3 ) and a reduction of $22 \%$ in glucose consumption (Figure 4). Again, the exception in glucose metabolism was the 1.2-fold increased maximal $\mathrm{HK}$ activity observed in the spleen LY when they were incubated in the presence of IFN $\alpha$ in comparison to control cells (Figure 3). Glutamine metabolism, on the other hand, was also reduced in these LY due to IFN $\alpha$ activity. Glutamine consumption decreased $21 \%$ and glutamine decarboxylation was reduced $23 \%$ in the presence of IFN $\alpha$ in comparison to control cells (Figure 4). Glutamine decarboxylation was accompanied by a reduction of $55.3 \%$ of the activity of important enzymes from the citric acid cycle (Figure 3 ).

\section{Discussion}

The antiproliferative effect of IFN $\alpha$ has been well described in different cell types [2] and has been related to the ability of these cytokines to affect several processes (e.g., protein synthesis) required for LY activation [5]. Herein, we demonstrate that glucose and glutamine metabolisms, particularly important for LY activation [17], are also modulated by IFN $\alpha$.

As expected, our results confirm the antiproliferative effect of IFN $\alpha$ on LY from mesenteric lymph nodes and the spleen. In fact, in a general sense, the cytokine promoted the same pattern of changes in the metabolism of LY from these diverse locations. Hence, the data of both LY populations will be discussed together.

Confirming the strict relation between substrate use and function in LY [11], the antiproliferative effect of IFN $\alpha$ was accompanied by a reduction in glucose and glutamine metabolisms. Thus, our results added the reduction of both substrates to the list of known factors related to the antiproliferative effect of IFN $\alpha$.

In spite of being a nonessential amino acid, several conditions such as infection and injuries can lead glutamine to become "conditionally essential". From this perspective, investigations about the rate of utilization of glutamine by immune cells have been performed aiming to open new ways of therapeutic manipulation of the proliferative, phagocytic, and secretory capacities of these cells [11]. As an example, the lymphocyte mitogen concanavalin A increased both glutaminase activity as well as glutamine utilization [28]. In this study, the antiproliferative effect of IFN $\alpha$ on LY was, however, accompanied by a reduction in glutaminase maximal activity and glutamine consumption. Furthermore, reductions of citrate synthase (CS) activity and of glutamine decarboxylation demonstrate that aerobic pathways linked to the metabolism of this amino acid were also affected by IFN $\alpha$.

Although both glucose and glutamine are utilized for energy production by LY, the first seems to be quantitatively more important [12]. In this study, LY cultured in the presence of IFN $\alpha$ consumed less total glucose and presented

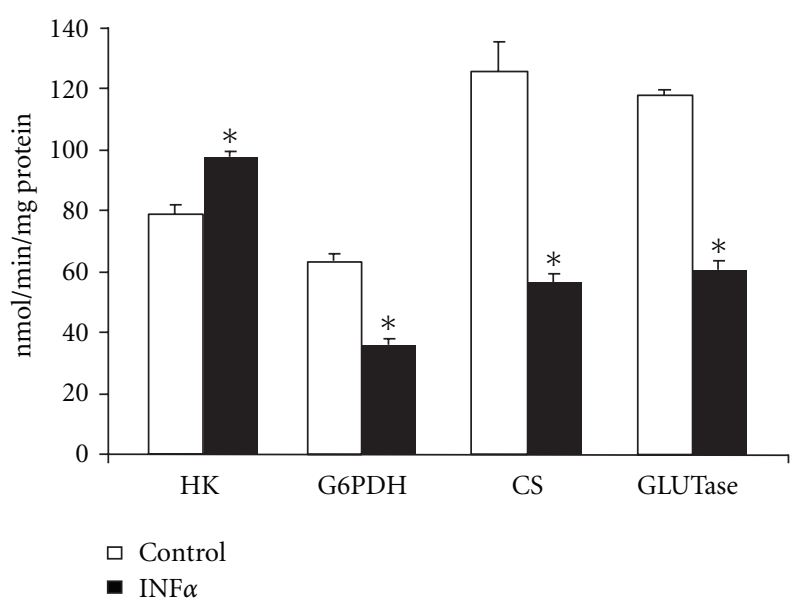

FIgURE 3: Maximal activity of enzymes of lymphocytes from spleen cultured in the presence or absence of IFN $\alpha$. The results are expressed as $\mathrm{nmol} / \mathrm{min}$ per $\mathrm{mg}$ of protein and represent the mean \pm SEM of 9 experiments. HK: hexokinase; G6PDH: glucose-6-phosphate dehydrogenase; CS: citrate synthase; GLUTase: phosphate dependent glutaminase. ${ }^{*} P<.05$ for comparison with the control (C) group.

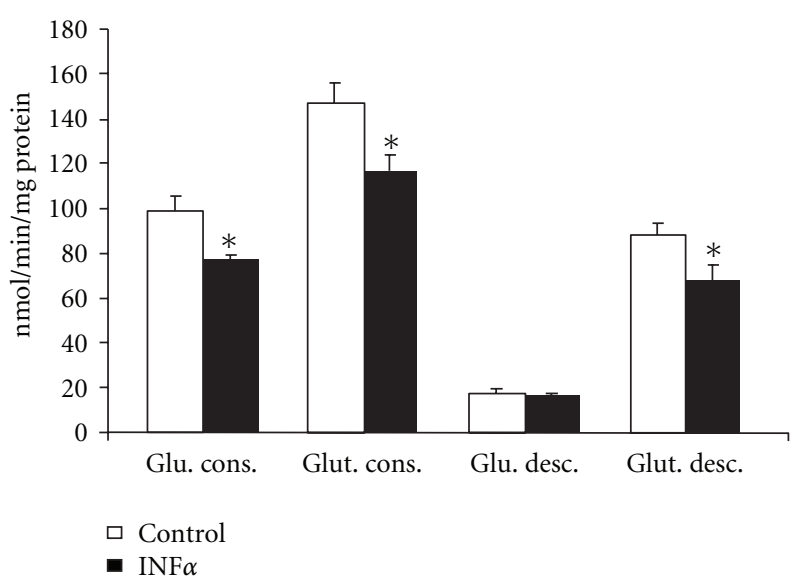

Figure 4: Consumption and decarboxylation of glucose and glutamine by lymphocytes from spleen cultured in the presence or absence of IFN $\alpha$. The results are expressed as $\mathrm{nmol} / \mathrm{min}$ per $\mathrm{mg}$ of protein and represent the mean \pm SEM of 9 experiments. ${ }^{*} P<.05$ for comparison with the control (C) group.

a reduced metabolism of this substrate by aerobic pathways as demonstrated by the minor glucose decarboxylation and activity of CS. Besides energy production, the reduction of the maximal activity of G6PDh, the first enzyme of the pentose-phosphate pathway, suggests that IFN $\alpha$ also compromises proliferation by reducing the production of metabolites and precursors needed for the biosynthesis of cell components essential for proliferation [29]. Still considering glucose metabolism, it is interesting to note that in spite of the reduced glucose consumption, IFN $\alpha$ increased the maximal activity of $\mathrm{HK}$ suggesting that the conversion of 
glucose to glucose-6-phosphate was not affected by this cytokine. Upon activation, LY increase their glucose uptake via GLUT1 [30]. Thus, even if the increased HK activity represents a greater glucose uptake in cultured LY the greater enzyme activity was not enough to promote an augment in glucose consumption because the subsequent processes of glucose metabolism were downregulated by IFN $\alpha$.

In accordance with MacIver et al. [30], the understanding of how normal LY function is regulated and fueled to allow production of ATP and biosynthetic precursors essential for growth and the effector function of these cells is very important due the severe downregulation of immune functions which result from LY deficiencies.

Additionally, because many cancer cells consume glucose in a manner similar to LY, that is, converting glucose to lactate even in the presence of enough oxygen [31], it is tempting to speculate that the results of the present study could be relevant for the understanding of the role of IFN $\alpha$ as an anticancer agent. Supporting this speculation, it has been demonstrated that different cancer cells can be resistant to IFN $\alpha[32,33]$. This effect could be associated with an inadequate activation of the JAK-STAT pathway and its effectors STAT1 and STAT2. In this scenario, while adequate levels of STAT1 are pivotal for the establishment of IFN $\alpha$ effects, low levels or overexpression of this transcription factor seems to be advantageous for tumor cells [32]. Interestingly, a previously uncharacterized role of STAT1 in regulating the expression of genes involved in glycolysis, citrate cycle, and oxidative phosphorylation has been recently demonstrated. On the other hand, we previously were able to demonstrate that LY of tumor-bearing rats presented reduced proliferation, glucose consumption, and maximal activity of enzymes such as G6PDH and CS, while simultaneously, Walker 256 tumor cells of the same animals presented an increased glucose metabolism [34].

As IFN $\alpha$ has antiapoptotic effects on activated LY [35] which are modulated by the metabolism of glucose and glutamine [15], the metabolism of these substrates and LY proliferation can be correlated with collagen-induced arthritis [16], and the high glucose and lipid levels observed in individuals with type 2 diabetes and obesity contribute to LY activity promoting inflammation [30]. The results presented here could be of relevance to other fields related with immunology.

Thus, further investigations concerning the molecular mechanisms underlying the effects of IFN $\alpha$ (and other cytokines) upon glucose and glutamine metabolisms as well as proliferation of LY could lead to the development of strategies to target cancer, autoimmune diseases and chronic diseases.

\section{Conclusions}

In conclusion, our data suggest that the inhibition of glucose and glutamine metabolism is an important part of the mechanism of the antiproliferative effect of IFN $\alpha$ in lymphocytes from rats.

\section{Acknowledgments}

The authors are grateful to Dr Niels Olsen Saraiva Câmara for his suggestions and comments in this investigation. This study was supported by Grants from FAPESP (97/3117-6).

\section{References}

[1] R. Gimeno, C. K. Lee, C. Schindler, and D. E. Levy, "Stat1 and Stat 2 but not Stat 3 arbitrate contradictory growth signals elicited by alpha/beta interferon in T lymphocytes," Molecular and Cellular Biology, vol. 25, no. 13, pp. 5456-5465, 2005.

[2] F. Romerio and D. Zella, "MEK and ERK inhibitors enhance the anti-proliferative effect of interferon-alpha2b," The FASEB Journal, vol. 16, no. 12, pp. 1680-1682, 2002.

[3] G. R. Klimpel, A. J. Infante, J. Patterson, C. B. Hess, and M. Asuncion, "Virus-induced interferon $\alpha / \beta$ (IFN- $\alpha / \beta)$ production by T cells and by Th1 and Th2 helper T cell clones: a study of the immunoregulatory actions of IFN- $\gamma$ versus IFN- $\alpha / \beta$ on functions of different T cell populations," Cellular Immunology, vol. 128, no. 2, pp. 603-618, 1990.

[4] D. M. Essayan, G. Krishnaswamy, A. Oriente, L. M. Lichtenstein, and S. K. Huang, "Differential regulation of antigeninduced IL-4 and IL-13 generation from T lymphocytes by IFN- $\alpha$," Journal of Allergy and Clinical Immunology, vol. 103, no. 3, pp. 451-457, 1999.

[5] M. A. McNurlan and M. J. Clemens, "Inhibition of cell proliferation by interferons. Relative contributions of changes in protein synthesis and breakdown to growth control of human lymphoblastoid cells," Biochemical Journal, vol. 237, no. 3, pp. 871-876, 1986.

[6] F. Buttgereit, G. R. Burmester, and M. D. Brand, "Bioenergetics of immune functions: fundamental and therapeutic aspects," Immunology Today, vol. 21, no. 4, pp. 192-199, 2000.

[7] T. Morgan, A. Wong, and C. Finch, "Anti-inflammatory mechanisms of dietary restriction in slowing aging processes," Interdisciplinary Topics in Gerontology, vol. 35, pp. 83-97, 2007.

[8] C. Franceschi, "Inflammaging as a major characteristic of old people: can it be prevented or cured?" Nutrition Reviews, vol. 65, no. 12, pp. S173-S176, 2007.

[9] S. Vasto, G. Candore, C. R. Balistreri et al., "Inflammatory networks in ageing, age-related diseases and longevity," Mechanisms of Ageing and Development, vol. 128, no. 1, pp. 83-91, 2007.

[10] S. A. Brod, "Unregulated inflammation shortens human functional longevity," Inflammation Research, vol. 49, no. 11, pp. 561-570, 2000.

[11] P. Newsholme, "Why is L-glutamine metabolism important to cells of the immune system in health, postinjury, surgery or infection?" Journal of Nutrition, vol. 131, no. 9, pp. 2515S2522S, 2001.

[12] P. C. Calder, G. Dimitriadis, and P. Newsholme, "Glucose metabolism in lymphoid and inflammatory cells and tissues," Current Opinion in Clinical Nutrition and Metabolic Care, vol. 10, no. 4, pp. 531-540, 2007.

[13] R. Curi, P. Newsholme, T. C. Pithon-Curi et al., "Metabolic fate of glutamine in lymphocytes, macrophages and neutrophils," Brazilian Journal of Medical and Biological Research, vol. 32, no. 1, pp. 15-21, 1999.

[14] R. F. P. Bacurau, M. A. Belmonte, M. C. L. Seelaender, and L. F. B. P. Costa Rosa, "Effect of a moderate intensity exercise training protocol on the metabolism of macrophages and 
lymphocytes of tumour-bearing rats," Cell Biochemistry and Function, vol. 18, no. 4, pp. 249-258, 2000.

[15] R. F. P. Bacurau, C. E. O’Toole, P. Newsholme, and L. F. B. P. Costa Rosa, "Sub-lethal concentrations of activated complement increase rat lymphocyte glutamine utilization and oxidation while lethal concentrations cause death by a mechanism involving ATP depletion," Cell Biochemistry and Function, vol. 20, no. 3, pp. 183-190, 2002.

[16] F. Navarro, A. V. N. Bacurau, S. S. Almeida et al., "Exercise prevents the effects of experimental arthritis on the metabolism and function of immune cells," Cell Biochemistry and Function, vol. 28, no. 4, pp. 266-273, 2010.

[17] M. S. M. Ardawi and E. A. Newsholme, "Maximum activities of some enzymes of glycolysis, the tricarboxylic acid cycle and ketone-body and glutamine utilization pathways in lymphocytes of the rat," Biochemical Journal, vol. 208, no. 3, pp. 743-748, 1982.

[18] R. Trinder, "Determination of glucose in blood using glucose oxidase with alternative oxygen acceptor," Annals of Clinical Biochemistry, vol. 6, no. 2, pp. 24-27, 1969.

[19] P. C. Engel and J. B. Jones, "Causes and elimination of erratic blanks in enzymatic metabolite assays involving the use of NAD in alkaline hydrazine buffers: improved conditions for the assay of 1-glutamate, 1-lactate, and other metabolites," Analytical Biochemistry, vol. 88, no. 2, pp. 475-484, 1978.

[20] H. G. Windmueller and A. E. Spaeth, "Uptake and metabolism of plasma glutamine by the small intestine," The Journal of Biological Chemistry, vol. 249, no. 16, pp. 5070-5079, 1974.

[21] R. Curi, P. Newsholme, and E. A. Newsholme, "Metabolism of pyruvate by isolated rat mesenteric lymphocytes, lymphocyte mitochondria and isolated mouse macrophages," Biochemical Journal, vol. 250, no. 2, pp. 383-388, 1988.

[22] J. M. Kowalchuk, R. Curi, and E. A. Newsholme, "Glutamine metabolism in isolated incubated adipocytes of the rat," Biochemical Journal, vol. 249, no. 3, pp. 705-708, 1988.

[23] H. U. Bergmeyer, E. Bernt, H. Mölering, and G. Pfleider, "L-aspartate and L-asparaginase," in Methods of enzymatic Analysis, H. U. Bergmeyer, Ed., pp. 1697-1700, Academic Press, London, UK, 1974.

[24] B. Crabtree and E. A. Newsholme, "The activities of phosphorylase, hexokinase, phosphofructokinase, lactate dehydrogenase and the glycerol 3-phosphate dehydrogenases in muscles from vertebrates and invertebrates," Biochemical Journal, vol. 126, no. 1, pp. 49-58, 1972.

[25] N. P. Curthoys and O. H. Lowry, "The distribution of glutaminase isoenzymes in the various structures of the nephron in normal, acidotic, and alkalotic rat kidney," The Journal of Biological Chemistry, vol. 248, no. 1, pp. 162-168, 1973.

[26] P. R. Alp, E. A. Newsholme, and V. A. Zammit, "Activities of citrate synthase and NAD linked and NADP linked isocitrate dehydrogenase in muscle from vertebrates and invertebrates," Biochemical Journal, vol. 154, no. 3, pp. 689-700, 1976.

[27] M. M. Bradford, "A rapid and sensitive method for the quantitation of microgram quantities of protein utilizing the principle of protein dye binding," Analytical Biochemistry, vol. 72, no. 1-2, pp. 248-254, 1976.

[28] K. Koyama, M. Kaya, J. Tsujita, and S. Hori, "Effects of decreased plasma glutamine concentrations on peripheral lymphocyte proliferation in rats," European Journal of Applied Physiology and Occupational Physiology, vol. 77, no. 1-2, pp. 25-31, 1998.
[29] F. Buttgereit and M. D. Brand, "A hierarchy of ATP-consuming processes in mammalian cells," Biochemical Journal, vol. 312, no. 1, pp. 163-167, 1995.

[30] N. J. MacIver, S. R. Jacobs, H. L. Wieman, J. A. Wofford, J. L. Coloff, and J. C. Rathmell, "Glucose metabolism in lymphocytes is a regulated process with significant effects on immune cell function and survival," Journal of Leukocyte Biology, vol. 84, no. 4, pp. 949-957, 2008.

[31] S. P. Pitroda, B. T. Wakim, R. F. Sood et al., "STAT1-dependent expression of energy metabolic pathways links tumour growth and radioresistance to the Warburg effect," BMC Medicine, vol. 7, article 68, 2009.

[32] R. J. Critchley-Thorne, N. Yan, S. Nacu, J. Weber, S. P. Holmes, and P. P. Lee, "Down-regulation of the interferon signaling pathway in $\mathrm{T}$ lymphocytes from patients with metastatic melanoma," PLoS Medicine, vol. 4, no. 5, article e176, pp. 0897-0911, 2007.

[33] D. Shang, Y. Liu, N. Ito, T. Kamoto, and O. Ogawa, "Defective Jak-Stat activation in renal cell carcinoma is associated with interferon- $\alpha$ resistance," Cancer Science, vol. 98, no. 8, pp. 1259-1264, 2007.

[34] A. V. N. Bacurau, M. A. Belmonte, F. Navarro et al., "Effect of a high-intensity exercise training on the metabolism and function of macrophages and lymphocytes of walker 256 tumor-bearing rats," Experimental Biology and Medicine, vol. 232, no. 10, pp. 1289-1299, 2007.

[35] E. Dondi, G. Roué, V. J. Yuste, S. A. Susin, and S. Pellegrini, "A dual role of IFN- $\alpha$ in the balance between proliferation and death of human $\mathrm{CD}^{+} \mathrm{T}$ lymphocytes during primary response," Journal of Immunology, vol. 173, no. 6, pp. 37403747, 2004. 


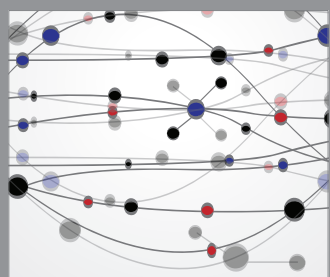

The Scientific World Journal
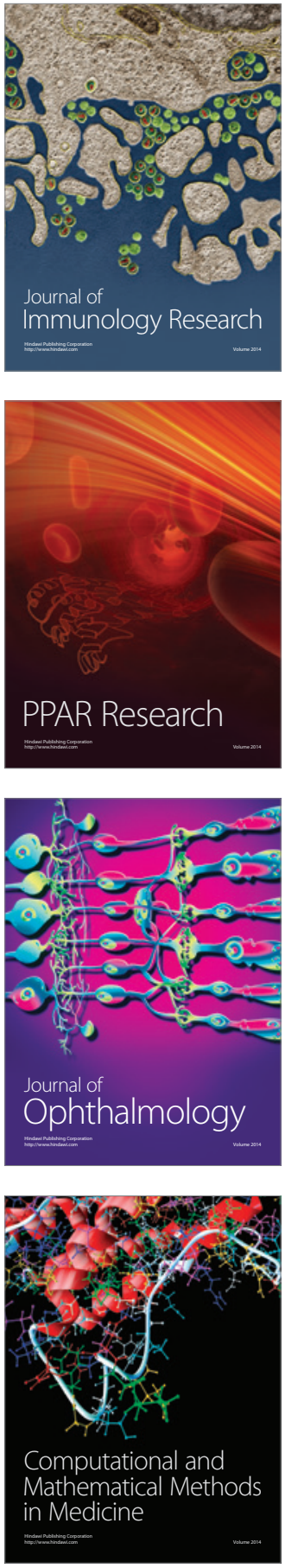

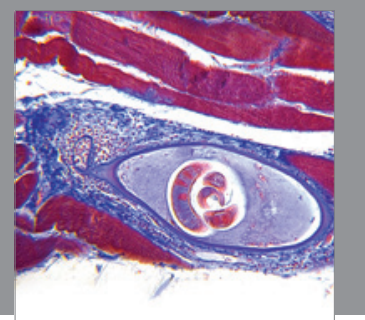

Gastroenterology

Research and Practice
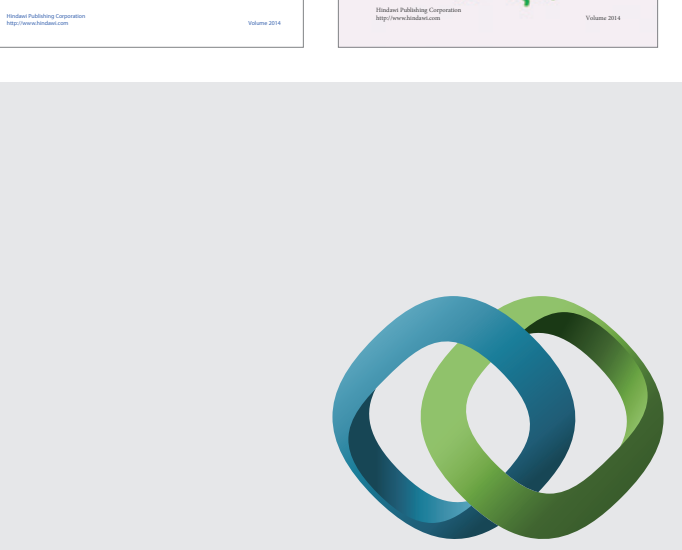

\section{Hindawi}

Submit your manuscripts at

http://www.hindawi.com
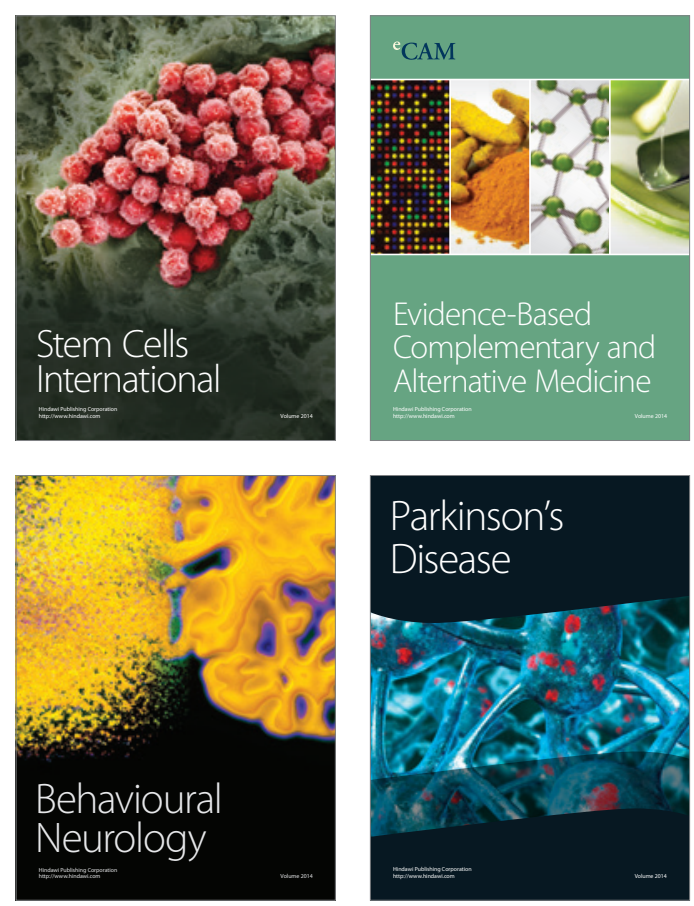

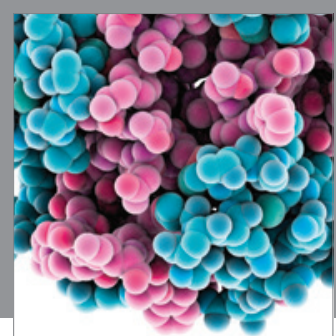

Journal of
Diabetes Research

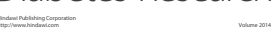

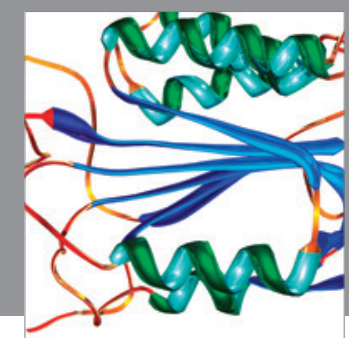

Disease Markers
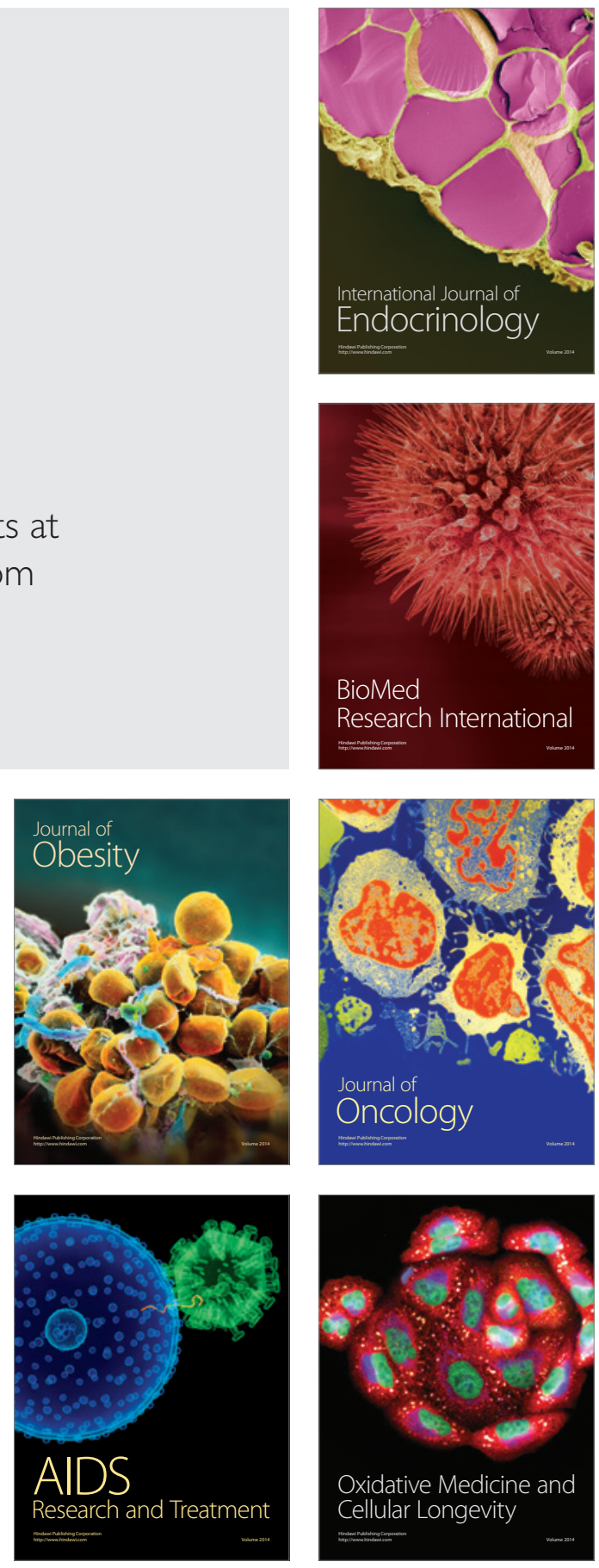